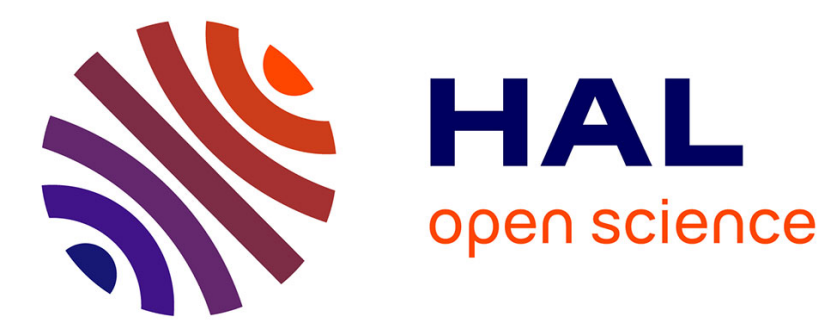

\title{
Modelling agronomic properties of Technosols constructed with urban wastes
}

S. Rokia, G. Séré, C. Schwartz, M. Deeb, F. Fournier, T. Nehls, O. Damas, L. Vidal-Beaudet

\section{- To cite this version:}

S. Rokia, G. Séré, C. Schwartz, M. Deeb, F. Fournier, et al.. Modelling agronomic properties of Technosols constructed with urban wastes. Waste Management, 2014, 34 (11), pp.2155-2162. 10.1016/j.wasman.2013.12.016 . hal-02173875

\section{HAL Id: hal-02173875 \\ https://hal.science/hal-02173875}

Submitted on 4 Jul 2019

HAL is a multi-disciplinary open access archive for the deposit and dissemination of scientific research documents, whether they are published or not. The documents may come from teaching and research institutions in France or abroad, or from public or private research centers.
L'archive ouverte pluridisciplinaire HAL, est destinée au dépôt et à la diffusion de documents scientifiques de niveau recherche, publiés ou non, émanant des établissements d'enseignement et de recherche français ou étrangers, des laboratoires publics ou privés. 
archives-ouvertes

\section{Modelling agronomic properties of Technosols constructed with urban wastes}

S. Rokia, G. Séré, C. Schwartz, M. Deeb, F. Fournier, T. Nehls, O. Damas, L. Vidal-Beaudet

\section{- To cite this version:}

S. Rokia, G. Séré, C. Schwartz, M. Deeb, F. Fournier, et al.. Modelling agronomic properties of Technosols constructed with urban wastes. Waste Management, Elsevier, 2014, 34 (11), pp.21552162. 10.1016/j.wasman.2013.12.016 . hal-02173875

\section{HAL Id: hal-02173875 \\ https://hal.archives-ouvertes.fr/hal-02173875}

Submitted on 4 Jul 2019

HAL is a multi-disciplinary open access archive for the deposit and dissemination of scientific research documents, whether they are published or not. The documents may come from teaching and research institutions in France or abroad, or from public or private research centers.
L'archive ouverte pluridisciplinaire HAL, est destinée au dépôt et à la diffusion de documents scientifiques de niveau recherche, publiés ou non, émanant des établissements d'enseignement et de recherche français ou étrangers, des laboratoires publics ou privés. 


\title{
Modelling agronomic properties of Technosols constructed with urban wastes
}

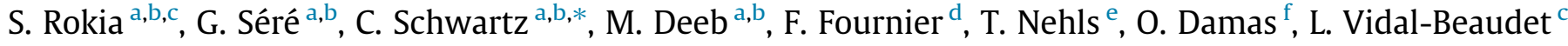 \\ a Laboratoire Sols et Environnement, Université de Lorraine, UMR 1120, TSA 40602, 54518 Vandœuvre-lès-Nancy Cedex, France \\ ${ }^{\mathrm{b}}$ Laboratoire Sols et Environnement, INRA, UMR 1120, TSA 40602, 54518 Vandouvre-lès-Nancy Cedex, France \\ 'Agrocampus Ouest - Centre d'Angers, Unité de Recherche EPHor, LUNAM Université, 49045 Angers Cedex, France \\ d Laboratoire Réactions et Génie des Procédés, CNRS UMR 7274, Université de Lorraine TSA 40602, 54518 Vandœuvre-lès-Nancy Cedex, France

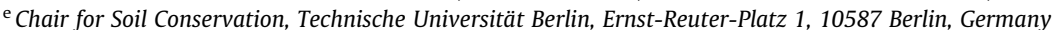 \\ ${ }^{\mathrm{f}}$ Plante et Cité, 49066 Angers, France
}

\section{A R T I C L E I N F O}

\section{Article history:}

Available online $\mathrm{xxxx}$

\section{Keywords:}

Constructed Technosol

Urban vegetation

Pedological engineering

Wastes formulation

Agronomic properties

Dose-response curves

\begin{abstract}
A B S T R A C T
The greening of urban and suburban areas requires large amounts of arable earth that is a non-renewable resource. However, concentration of population in cities leads to the production of high amounts of wastes and by-products that are nowadays partly recycled as a resource and quite systematically exported out of urban areas. To preserve natural soil resources, a strategy of waste recycling as fertile substitutes is proposed. Eleven wastes are selected for their environmental harmlessness and their contrasted physico-chemical properties for their potential use in pedological engineering. The aim is (i) to demonstrate the feasibility of the formulation of fertile substrates exclusively with wastes and (ii) to model their physico-chemical properties following various types, number and proportions of constitutive wastes. Twenty-five binary and ternary combinations are tested at different ratios for total carbon, Olsen available phosphorus, cation exchange capacity, water $\mathrm{pH}$, water retention capacity and bulk density. Dose-response curves describe the variation of physico-chemical properties of mixtures depending on the type and ratio of selected wastes. If these mixtures mainly mimic natural soils, some of them present more extreme urban soil features, especially for $\mathrm{pH}$ and $P_{\mathrm{Olsen}}$. The fertility of the new substrates is modelled by multilinear regressions for the main soil properties.
\end{abstract}

\section{Introduction}

Is it possible to recycle urban wastes for the construction of fertile soils in cities as a substitute for natural soil resources? plants in urban environments present a growing interest in daily life, health and well-being (Nielsen and Hansen, 2007). Indeed, green areas present advantages regarding biodiversity, urban water infiltration and also contribute to the decrease of urban heat island phenomenon (Lorenz and Lal, 2009). However, soils in urban areas are mainly not favourable mediums for plant growth considering their low physical and chemical fertility (Jim, 1998). Urban soils are characterised by a high spatial heterogeneity as a result of the mixture of technogenic artefacts in Technosols (WRB, 2006) with native materials (Morel et al., 2005). These soils are characterised by (i) coarse texture; (ii) extreme values of bulk density that are either high $\left(>1.6 \mathrm{~g} \mathrm{~cm}^{-3}\right)$ or very low $\left(<0.5 \mathrm{~g} \mathrm{~cm}^{-3}\right)$; (iii) high $\mathrm{pH}$ values $(\mathrm{pH}>7.5)$ resulting from alkalising products mixed in the soil;

* Corresponding author at: Laboratoire Sols et Environnement, Université de Lorraine, UMR 1120, TSA 40602, 54518 Vandœuvre-lès-Nancy Cedex, France. Tel.: +33 383595854 .

E-mail address: christophe.schwartz@univ-lorraine.fr (C. Schwartz). (iv) high $C / N$ ratio because of a low $N$ content; and (v) potentially enhanced pollution level (Morel et al., 2005). Therefore, to insure the implementation of urban green areas, large quantities of upper soil materials imported from agricultural or forestlands are needed (in France 3 millions of $\mathrm{m}^{3}$ year $^{-1}$ ). At the same time, cities consume high quantities of raw materials that give rise to great amounts of urban wastes (e.g., rubble, household refuse, industrial wastes and by-products). In France, 770 million tons of wastes and by-products (called "wastes" in the article) were produced in 2009 , 5.3 million tons corresponding to municipal wastes (public refuse, sewage sludge, and green wastes), 253 million tons to wastes resulting from civil engineering, 32 million tons to household wastes, 106 million tons to industrial wastes and 374 million tons to wastes from forest and agriculture (ADEME, 2012). These wastes are consistently exported out of cities, part of them being recycled into industrial processes, others directly spread on agricultural soils (e.g., compost, urban and industrial sludge) and most of them landfilled (Marshall and Farahbakhsh, 2013).

The aim of the present work is to limit the exportation of wastes out of cities by recycling them in urban soil construction. Some previous experiments have been led by mixing wastes together 
(e.g., sewage sludge, compost, and paper mill sludge) to restore industrial brownfields (Fierro et al., 1999; Séré et al., 2008) or by adding organic wastes to planting holes (Craul, 1999; Grosbellet et al., 2011). But, in these particular studies few wastes ratios have been well investigated. Thus the complexity of the potential interactions in the wastes combination could not be understood. Moreover, the question of reaching the optimum wastes ratio in the mixture stays unanswered, whereas this step is required to develop at a larger scale pedological engineering by the recycling of urban wastes into constructed soils. The aim of this study is to provide answers to the following questions: (i) Is it feasible to create fertile substrates, which mimic natural soils, exclusively with wastes? (ii) Is it possible to describe with appropriate models the variation of physico-chemical properties of mixtures constituted by various proportions of wastes? (iii) Is the fertility of these mixtures predictable out of the characteristics of the constitutive materials?

\section{Materials and methods}

\subsection{Selection of wastes}

A national research program funded by the French environmental agency (programme SITERRE-ADEME) is dedicated to the development of pedological engineering for the construction of soils in urban areas. During this program, eleven wastes have been selected in the European waste catalogue (European commission $n^{\circ}$ $94 / 3 / C E E, 1993)$. The criteria of selection were: the volume of production, the availability all over the French regions, the low toxicity and the potential fertility as mineral and/or organic constituents for soil construction. The eleven wastes are: excavated acidic and basic earth material from a deep horizon (respectively AE and BE, European classification number: 170504), bricks (BR, 170102-170103), compost made off sewage sludge and green wastes (CO, 190503), concrete (CR, 170101), demolition rubble (DR, 170107), green wastes (GW, 020107-020103), paper-mill sludge (PM, 030305), street sweeping wastes (SS, 200303), sewage sludge (SW, 190812), and track ballast (TB, 170508). Five of them are mainly organic (CO, GW, PM, SS, SW) and six are mainly mineral materials (AE, BE, BR, CR, DR, TB). Among them, only two are fine earth materials, developed on acidic and basic bedrocks (AE, $\mathrm{BE}$ ). These last are classified as wastes but can be considered as natural soil resources, even if excavated from deeper horizons.

\subsection{Sampling of wastes}

Ten cubic meters of each waste have been collected from local cities and companies and stored on a platform before sampling (Angers, France, $47^{\circ} 47^{\prime} \mathrm{N}, 00^{\circ} 56^{\prime} \mathrm{W}$ ). Fifty kilograms of homogeneous samples representative for each pile of waste have been obtained by the mixing of 20 sub-samples.

\subsection{Selection of waste mixtures}

To reduce the complexity of the systems, the number of wastes mixed together was limited to 3 . Using the 11 wastes, they were 45 binary and 120 ternary possible combinations. For technical reasons in relation with the size of the experiment, we decided to limit the number of characterised mixtures to 25 . The first filter was to eliminate the nonsensical associations regarding the construction of fertile soils. Obviously, the mixtures of materials with very similar properties and the binary combinations of two mineral or two organic materials were not studied. In prevision of the construction of dose-response curves, fifteen binary combinations have been prepared at 5 different ratios ranking from 0/100, 20/80, 50/50,
$80 / 20$, to $100 / 0$ (volume waste $1 /$ volume waste 2 ) (Table 1 ). For the ternary mixtures, we followed the model of structural soils including systematically $60 \% \mathrm{v} / \mathrm{v}$ of coarse mineral material $(\mathrm{CR}$, DR, TB) (Grabosky et al., 2002). They were added with 40\% v/v of binary mixtures constituted by $10 \%, 20 \%$ or $30 \%$ (volume waste $1 /$ volume waste 2 ) of two other materials: organic wastes (CO, GW, PM, SS, SW) and earth materials (AE, BE) (Table 1). This procedure allowed preparing, at all, 75 mixtures contrasted for their composition (25 combinations) and different ratios.

\subsection{Mixing procedure}

At a first step, all the wastes have been air-dried. Coarse wastes (CR, DR, BR, TB) have been crushed at $5 \mathrm{~mm}$. All the materials have then been sieved at $5 \mathrm{~mm}$. The experimental devices used for the mixing procedure were $2 \mathrm{~L}$ cylinder shaped flasks (Nalgene, $100 \mathrm{~mm}$ diameter, $250 \mathrm{~mm}$ height). This size has been selected because the maximum grain diameter of mixed materials should be at least 10 times smaller than the diameter of the experimental device (Paute et al., 1994). The wastes have been moistened at $80 \% \mathrm{w} /$ $\mathrm{w}$ of their water field capacity. They have been weight, mixed, and homogenised manually during $5 \mathrm{~min}$, before being incorporated in the $2 \mathrm{~L}$ flasks and put successively vertically (16 rpm, for $10 \mathrm{~min}$ ) and horizontally (16 rpm, for $10 \mathrm{~min}$ ) on a rotating shaker (Guyon and Troadec, 1994; Khakhar, 2011; Severson et al., 2007). Bulk density has been determined on these samples following a method adapted from the standard NF EN 13041.

\subsection{Agronomic characterisation}

The mixtures of wastes have been investigated for their ability to support plant biomass production. Both wastes and mixtures have been air dried and sieved at $2 \mathrm{~mm}$. Classical soil indicator attributes have been selected to characterize the fertility of the mixtures of technogenic materials. The samples have been characterised for total $C\left(C_{\text {tot }}\right)$, available phosphorus $\left(P_{\text {Olsen }}\right)$, cation exchange capacity (CEC), $\mathrm{pH}$ (water), and characteristic humidity at field capacity (matrix potential: $-10 \mathrm{kPa})\left(\mathrm{WC}_{-10 \mathrm{kPa}}\right.$ ) using standard methods for soils (NF ISO 10694, NF ISO 11263, NF X 31130 NF ISO 10390, NF ISO 11464 respectively). The characteristics of the mixtures have been compared to statistics calculated from the 2200 sites of the French National Soil Monitoring Network "Réseau de Mesures de la Qualité des Sols" (Jolivet et al., 2006; Arrouays et al., 2002), which consists of soil property observations on a $16-\mathrm{km}$ regular grid covering the French metropolitan territory $\left(5550,000 \mathrm{~km}^{2}\right)$.

\subsection{Statistic tools}

Data relative to the waste characterisation $\left(C_{\text {tot }}, P_{\text {Olsen }}, \mathrm{CEC}, \mathrm{pH}\right.$, $\mathrm{WC}_{-10 \mathrm{kPa}}$, bulk density) were submitted to principal component analysis using XLSTAT software (2011.2.06 version).

\subsection{Modelling details and validation}

Waste mixtures characteristics were modelled using second order polynomial models without interaction terms (Matlab, R2010a). Models include the 11 factors describing the composition of each waste material. One model was determined for each characteristic $\left(C_{\text {tot }}, P_{\text {Olsen }}, \mathrm{CEC}, \mathrm{pH}, \mathrm{WC}_{-10 \mathrm{kPa}}\right.$, bulk density). Each experience was repeated three times. The linear regression was performed on a set of 86 samples including pure (11), binary (45) and ternary (30) mixtures. Model quality was assessed using determination coefficient $\left(R^{2}\right)$. As a validation step, the model was tested with characterisation data for 4 organic wastes ( $\mathrm{CO}$, GW, SS and SW) from a new origin. Twelve mixtures (four binary 
Table 1

Mixtures tested for each material type.

\begin{tabular}{|c|c|c|}
\hline & Binary mixtures & Ternary mixtures \\
\hline $\begin{array}{l}\text { Mineral and organic } \\
\text { wastes }\end{array}$ & $\begin{array}{l}\mathrm{AE} / \mathrm{CO}, \mathrm{AE} / \mathrm{GW}, \mathrm{AE} / \mathrm{PM}, \mathrm{AE} / \mathrm{SS}, \mathrm{AE} / \mathrm{SW}, \mathrm{BE} / \mathrm{CO}, \mathrm{BE} / \mathrm{SS}, \mathrm{BR} / \mathrm{CO} \text {, } \\
\mathrm{BR} / \mathrm{PM}, \mathrm{TB} / \mathrm{CO}, \mathrm{TB} / \mathrm{PM}\end{array}$ & $\begin{array}{l}\mathrm{AE} / \mathrm{CR} / \mathrm{GW}, \mathrm{AE} / \mathrm{CR} / \mathrm{SS}, \mathrm{AE} / \mathrm{CR} / \mathrm{SW}, \mathrm{AE} / \mathrm{DR} / \mathrm{CO}, \mathrm{AE} / \mathrm{TB} / \mathrm{SS}, \mathrm{AE} / \mathrm{TB} / \mathrm{SW}, \mathrm{BE} / \mathrm{TB} / \mathrm{PM}, \mathrm{BE} / \\
\mathrm{TB} / \mathrm{SS}, \mathrm{BE} / \mathrm{TB} / \mathrm{SW}, \mathrm{TB} / \mathrm{SS} / \mathrm{CO}\end{array}$ \\
\hline Mineral wastes & $\mathrm{AE} / \mathrm{BR}, \mathrm{AE} / \mathrm{CR}, \mathrm{AE} / \mathrm{DR}, \mathrm{AE} / \mathrm{TB}$ & \\
\hline
\end{tabular}

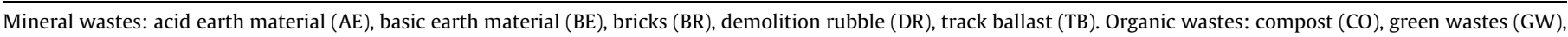
paper mill sludge (PM), street sweeping wastes (SS), sewage sludge (SW).

and 8 ternary) have been realised with these "new wastes" and experimental data were compared to the predicted data. These materials were not used for the initial regression but were sampled and prepared following the same protocols as described before (Sections 2.2 and 2.3).

\section{Results}

\subsection{Characterisation of the fertility}

\subsubsection{Physico-chemical properties of the wastes}

Total carbon concentrations were ranging from 0.8 to $278 \mathrm{~g} \mathrm{~kg}^{-1}$ (Table 2). Two main groups can be distinguished: the organic wastes exhibited $C_{\text {tot }}$ concentrations higher than $100 \mathrm{~g} \mathrm{~kg}^{-1}$ (CO, GW, PM, SS, SW) whereas the mineral wastes had contents lower than $30 \mathrm{~g} \mathrm{~kg}^{-1}$ (AE, BE, BR, CR, DR, TB). Concerning the organic wastes, three of them ( $\mathrm{CO}, \mathrm{GW}$ and $\mathrm{SW})$ were free of carbonates $\left(C_{\min }<1 \mathrm{~g} \mathrm{~kg}^{-1}\right)$ and the entire $C$ can consequently be assimilated to organic carbon $\left(C_{\text {org }}\right)$ ranging from 173 to $278 \mathrm{~g} \mathrm{~kg}^{-1}$. On the contrary, the carbon type for PM and SS was partly mineral with significant carbonate contents of 601 and $54.5 \mathrm{~g} \mathrm{~kg}^{-1}$ respectively, which implied $C_{\text {org }}$ concentrations of $148 \mathrm{~g} \mathrm{~kg}^{-1}$ and $134 \mathrm{~g} \mathrm{~kg}^{-1}$. For these five organic wastes, $\mathrm{pH}$ was globally alkaline and ranking from 7.8 to 8.7. The $C$ concentration of the mineral wastes distributing from 0.8 to $26.2 \mathrm{~g} \mathrm{~kg}^{-1}$ was linked to the carbonate concentrations. More than $50 \%$ of $C_{\text {tot }}$ of $\mathrm{BR}, \mathrm{CR}$ and DR were mineral and associated to high calcareous contents $\left(89,112\right.$ and $114 \mathrm{~g} \mathrm{~kg}^{-1}$ respectively) with low or very low $C_{\text {org }}$ concentrations (<quantification limit, 13.3 and $6.6 \mathrm{~g} \mathrm{~kg}^{-1}$ respectively). As a consequence of their carbonates contents, their $\mathrm{pH}$ is quite high $\left(9.1,10.1\right.$, and 10.3). The $C_{\text {tot }}$ concentrations of $\mathrm{AE}$, $\mathrm{BE}$ and $\mathrm{TB}$ were negligible $\left(0.8,0.9\right.$ and $1.1 \mathrm{~g} \mathrm{~kg}^{-1}$ respectively). $\mathrm{BE}$ and $\mathrm{TB}$ were alkaline $(8.2,9.4)$ and $\mathrm{AE}$ was acid (5.6).

Concerning the availability of nutrients, SW, GW and CO were especially characterised by high $P_{\text {Olsen }}$ concentrations ranging from 0.96 to $4.93 \mathrm{~g} \mathrm{~kg}^{-1}$, associated to a high CEC $\left(>40 \mathrm{cmol}+\mathrm{kg}^{-1}\right)$. Paper mill sludge (PM) and SS showed intermediate values for $P_{\text {Olsen }}$ $\left(0.1,0.21 \mathrm{~g} \mathrm{~kg}^{-1}\right)$ and $\operatorname{CEC}\left(7.8,21.5 \mathrm{cmol}+\mathrm{kg}^{-1}\right)$. The mineral wastes were mainly characterised by low $P_{\text {Olsen }}$ concentrations $\left(<0.12 \mathrm{~g} \mathrm{~kg}^{-1}\right)$ and low CEC $\left(<7 \mathrm{cmol}+\mathrm{kg}^{-1}\right)$. Concerning the physical properties, the organic wastes show high $\mathrm{WC}_{-10 \mathrm{kPa}}$ grading from $36.8 \%$ to $172 \% \mathrm{w} / \mathrm{w}$ and low bulk density values ranking from 0.6 to $0.9 \mathrm{~g} \mathrm{~cm}^{-3}$. On the contrary, the second main group of mineral wastes is characterised by lower $\mathrm{WC}_{-10 \mathrm{kPa}}$ values distributing from $8.5 \%$ to $31.1 \% \mathrm{w} / \mathrm{w}$ and higher bulk density values ranking from 1.1 to $1.7 \mathrm{~g} \mathrm{~cm}^{-3}$.

The 11 wastes were initially selected for their contrasted and complementary physico-chemical properties based on data classically presented in the international literature. The results (i) confirmed the expected properties of the materials and (ii) gave additional and original characterisations of the potential fertility of the wastes (e.g. availability of nutrients). A descriptive statistical analysis was conducted on all the data with the exception of the two extreme wastes (SW as the most organic material and $\mathrm{AE}$ as the only acidic material $\mathrm{pH}<6$ ). This approach reinforced three contrasted groups of wastes (Fig. 1): (i) mineral wastes with high $\mathrm{pH}$ and/or bulk density (DR, CR, TB, BR and BE), (ii) organic wastes with high water and nutrient availability (CO and GW) and (iii) intermediate organo-mineral materials (PM, SS). So, the selected set of wastes was well and truly constituted of contrasted materials exhibiting valuable characteristics as far as agronomic and geomechanical properties are concerned. However, none of the wastes that were studied can be considered as an efficient growing medium in itself. This is confirmed when comparing agronomic characteristics with the optimal data for plant growth proposed by Craul (1999) (e.g., pH should range from 6.0 to 7.5, CEC from 5 to $25 \mathrm{cmol}+\mathrm{kg}^{-1}$, and bulk density from 1.1 to $1.4 \mathrm{~g} \mathrm{~cm}^{3}$ ). Thus, the results also emphasized the relevance of mixing wastes to construct fertile and functional soils for green areas.

\subsubsection{Physico-chemical properties of the mixtures}

In this part, exclusively characterisations of wastes mixtures are statistically presented in box-plots (Fig. 2). The values of $C_{\text {tot }}$ in the 75 mixtures varied greatly from 0.4 to $161 \mathrm{~g} \mathrm{~kg}^{-1}$ with three quarters of the values ranging from 0.40 to $47.8 \mathrm{~g} \mathrm{~kg}^{-1}$ (Fig. 2). Concerning $P_{\text {Olsen }}$, the concentrations for the mixtures were varying from 0.02 to $3.83 \mathrm{~g} \mathrm{~kg}^{-1}$ with three quarters of the values comprised between 0.02 and $0.48 \mathrm{~g} \mathrm{~kg}^{-1}$. The CEC ratio was grading from 0.97 to

Table 2

Physico-chemical characteristics of the products used in mixtures (for the dry matter).

\begin{tabular}{|c|c|c|c|c|c|c|c|c|c|c|c|c|}
\hline \multirow{3}{*}{$\begin{array}{l}\text { Sample code } \\
\mathrm{AE}\end{array}$} & \multicolumn{8}{|c|}{ Chemistry } & \multicolumn{4}{|c|}{ Physics } \\
\hline & \multicolumn{2}{|c|}{$C_{\text {tot }}\left(\mathrm{g} \mathrm{kg}^{-1}\right)$} & \multicolumn{2}{|c|}{$P_{\text {Olsen }}\left(\mathrm{g} \mathrm{kg}^{-1}\right)$} & \multicolumn{2}{|c|}{$\mathrm{CEC}\left(\mathrm{cmol}+\mathrm{kg}^{-1}\right)$} & \multicolumn{2}{|l|}{$\mathrm{pH}$} & \multicolumn{2}{|c|}{$\mathrm{WC}_{-10 \mathrm{kPa}}(\%(\mathrm{w} / \mathrm{w}))$} & \multicolumn{2}{|c|}{$\mathrm{BD}\left(\mathrm{g} \mathrm{cm}^{-3}\right)$} \\
\hline & 0.8 & $(0.1)$ & 0.01 & $(0.01)$ & 1.57 & $(0.03)$ & 5.6 & $(0.01)$ & 22.6 & $(0.8)$ & 1.5 & $(0.05)$ \\
\hline $\mathrm{BE}$ & 0.9 & $(0.1)$ & 0.01 & $(0.01)$ & 2.23 & $(0.05)$ & 8.2 & $(0.01)$ & 31.1 & $(0.2)$ & 1.4 & $(0.05)$ \\
\hline BR & 11.7 & (1.5) & 0.03 & $(0.01)$ & 1.37 & $(0.10)$ & 9.1 & $(0.08)$ & 25.4 & $(0.1)$ & 1.1 & $(0.05)$ \\
\hline $\mathrm{CO}$ & 173 & $(2.6)$ & 0.96 & $(0.01)$ & 56.4 & $(2.80)$ & 8.4 & $(0.01)$ & 53.0 & $(0.7)$ & 0.6 & $(0.01)$ \\
\hline CR & 26.2 & (5.1) & 0.04 & $(0.01)$ & 4.69 & $(0.08)$ & 10.1 & $(0.01)$ & 14.5 & $(0.8)$ & 1.4 & $(0.05)$ \\
\hline DR & 20.2 & $(2.3)$ & 0.12 & $(0.01)$ & 3.46 & $(0.40)$ & 10.3 & $(0.01)$ & 23.8 & $(0.7)$ & 1.4 & $(0.05)$ \\
\hline GW & 198 & (7.7) & 1.09 & $(0.01)$ & 48.4 & (3.50) & 7.8 & $(0.01)$ & 87.6 & (3.6) & 0.6 & $(0.01)$ \\
\hline PM & 185 & $(2.6)$ & 0.10 & $(0.01)$ & 7.78 & $(0.01)$ & 8.7 & $(0.08)$ & 43.7 & $(1.5)$ & 0.9 & $(0.01)$ \\
\hline SS & 153 & (6.5) & 0.21 & $(0.01)$ & 21.5 & $(1.50)$ & 8.1 & $(0.01)$ & 36.8 & (5.1) & 0.8 & $(0.01)$ \\
\hline SW & 278 & $(5.4)$ & 4.93 & $(0.01)$ & 69.6 & $(1.20)$ & 7.9 & $(0.01)$ & 172 & $(7.4)$ & 0.8 & $(0.01)$ \\
\hline ТВ & 1.1 & $(0.2)$ & 0.03 & $(0.01)$ & 6.81 & $(0.10)$ & 9.4 & $(0.03)$ & 8.5 & $(0.2)$ & 1.7 & $(0.05)$ \\
\hline
\end{tabular}

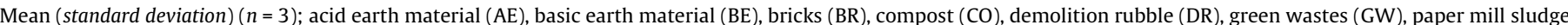
(PM), street sweeping wastes (SS), sewage sludge (SW), track ballast (TB). 

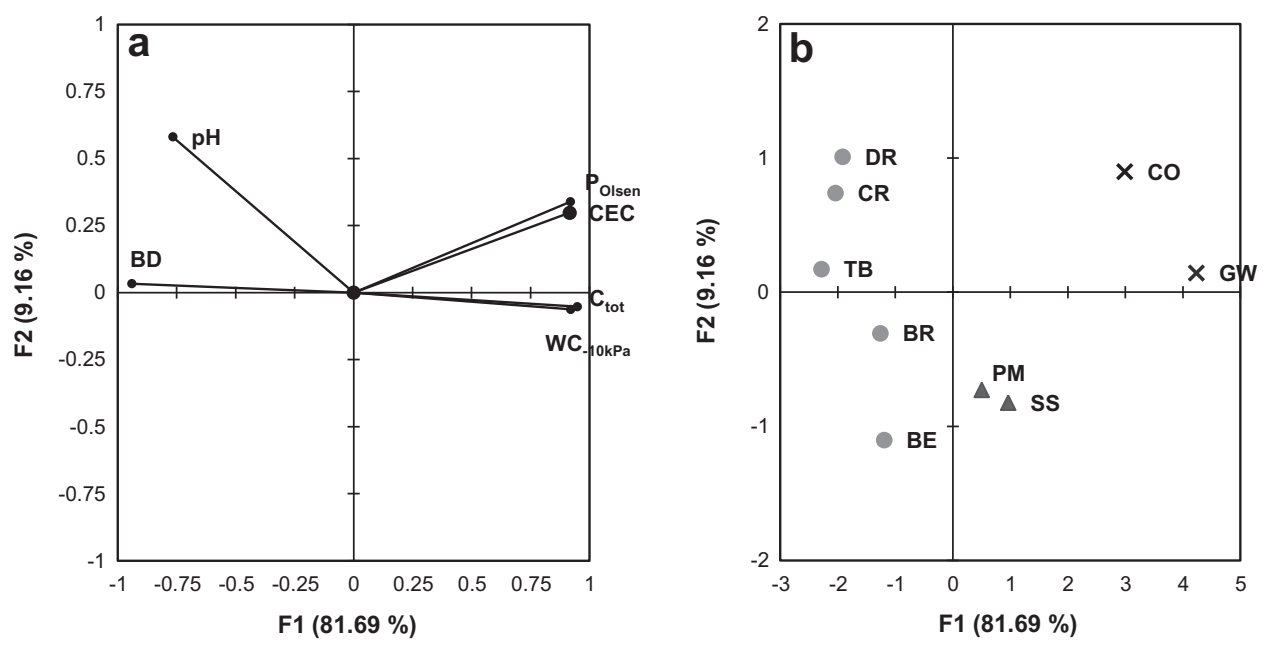

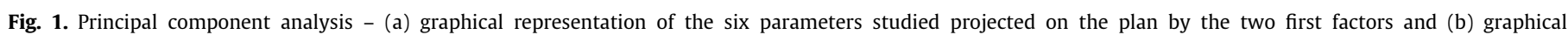
representation of the nine materials projected on the plan by the two first factors.

$43.3 \mathrm{cmol}+\mathrm{kg}^{-1}$ with half of the mixtures between 3.14 and $9.68 \mathrm{cmol}+\mathrm{kg}^{-1}$. The $\mathrm{pH}$ of the mixtures was between 5.7 and 9.9 with three quarters of the mixtures from 5.7 to 8.9. Concerning physical properties, $\mathrm{WC}_{-10 \mathrm{kPa}}$ of the mixtures was distributing from $8.9 \%$ to $81.4 \% \mathrm{w} / \mathrm{w}$ with three quarters of the mixtures comprised between $8.9 \%$ and $32.7 \% \mathrm{w} / \mathrm{w}$. The bulk density presented a homogeneous distribution with values grading from 0.8 to $1.6 \mathrm{~g} \mathrm{~cm}^{-3}$. Half of the bulk density values of the mixtures were comprised between 1.1 and $1.4 \mathrm{~g} \mathrm{~cm}^{-3}$.

\subsubsection{Dose-response curves of the addition of a waste to another}

The representation of dose response curves described the variation of physico-chemical properties depending on the proportions of each waste in the mixtures. Data are presented successively for chemical (Fig. 3A-D) and physical (Fig. 3E and F) fertility parameters. For all the mixtures involving organic wastes, the parameters of $C_{\text {tot }}, P_{\text {Olsen }}$ and CEC can be modelled by regression curves fitting the experimental data with $R^{2}>0.7$ and the fitness was even greater for the ternary mixtures $\left(R^{2}>0.8\right)$ (Fig. 3A.a, B.a, and C.a). Concerning the binary mixtures involving $\mathrm{AE}$ with mineral wastes, $C_{\text {tot }}$ can be modelled with a good fitness for AE/CR and AE/DR $\left(R^{2}>0.8\right)$ but not for $\mathrm{AE} / \mathrm{TB}$ and $\mathrm{AE} / \mathrm{BR}\left(R^{2}<0.6\right)$. $P_{\text {Olsen }}$ and CEC can be modelled with a good fitness for the mixtures involving $\mathrm{CR}, \mathrm{DR}$ and TB $\left(R^{2}>0.8\right)$. For the mixture involving $\mathrm{BR}$, the modelling of the variation of $P_{\text {Olsen }}$ and CEC is heterogeneously fitting the data with $R^{2}$ of respectively 0.7 and 0.05 . For all the mixtures involving organic materials, regression curves of $\mathrm{pH}$ did not represent the experimental data with a good fitness $\left(R^{2}<0.6\right)$, mainly because most of the $\mathrm{pH}$ values are closed to 8.5 (Fig. 3D.a and D.b). The $\mathrm{pH}$ of the binary mixtures of AE with the four other mineral wastes can be modelled with a rather good fitness $\left(R^{2}>0.7\right)$ (Fig. 3D.c). For all types of associations, the modelling of $\mathrm{WC}_{-10 \mathrm{kPa}}$ and bulk density with regression curves fitted the data with $R^{2}>0.7$, except regarding bulk density for two mixtures: AE/SW and AE/DR $\left(R^{2}<0.5\right)$ (Fig. 3E and F). The best regressions were obtained for $P_{\text {Olsen }}$ and WC $-10 \mathrm{kPa}\left(R^{2}>0.7\right)$. As fitness was not systematically satisfactory, it justified the exploration of other models to describe the variation of the fertility of mixtures at different ratios.

\subsection{Modelling of the mixtures properties}

Initial characteristics data of parent materials were inferred to estimate material mixtures properties.
It was indeed noticed that the model based on mass balance for $C$ was not satisfactory. Polynomial models were thus considered. At a second step, linear and quadratic terms were accounted for:

$Y=a_{0}+\sum_{i=1}^{11} a_{i} X_{i}+\sum_{i=1}^{11} a_{i i} X_{i}^{2}$

For each characteristic, regressions were plotted (Fig. 4) and determination coefficients were calculated. Globally, such polynomial models fitted each characteristic with coefficients ranging from 0.86 to 0.99 ( $C_{\text {tot }} 0.90, P_{\text {Olsen }} 0.97$, CEC 0.99, $\mathrm{pH} 0.86$, WC $-10 \mathrm{kPa}$ 0.99 , bulk density 0.97$)$. The models performed reproduced a great diversity of experimental data obtained on a great diversity of media mixtures (data input $=516$ ) with good fitness.

As a validation step, the transposition capability of the model to four "new wastes" has been evaluated. The second dataset produced by the model with modified initial data was compared to experimental data (12 mixtures). The regressions obtained showed 2 outliers: BE/TB/SW and CR/SS/BR. After removing them, the coefficients obtained were more satisfactory for most of the parameters. Three prediction capability levels have been distinguished: (i) models for bulk density and $\mathrm{WC}_{-10 \mathrm{kPa}}$ were validated; (ii) models for $P_{\text {Olsen }}$ and CEC, present intermediate prediction capability; and (iii) models for $C_{\text {tot }}$ and $\mathrm{pH}$ were not validated. The deviations observed can be explained by the size of the data set used for this validation step (data input $=10$ ) compared to the size of the modelling data set.

\section{Discussion}

\subsection{Characteristics and typology of wastes}

Regarding agronomic properties, no individual waste material can be assimilated to a natural soil or horticultural substrate. However, each waste presents a potential fertility regarding physical or chemical properties. Thus, each waste will play a specific role in mixtures. Some wastes (e.g., CO, GW and SW) are commonly applied as organic fertilizers in agricultural and also on reclaimed derelict soils because they potentially improve soil chemical fertility (Singh and Agrawal, 2008; Wright et al., 2008). Our descriptive statistical analysis demonstrated their singularity (Fig. 1). But first and foremost, the dose-response curves highlighted that these three wastes play a major role in mixtures by imposing their properties, especially for chemical characteristics and even at low ra- 

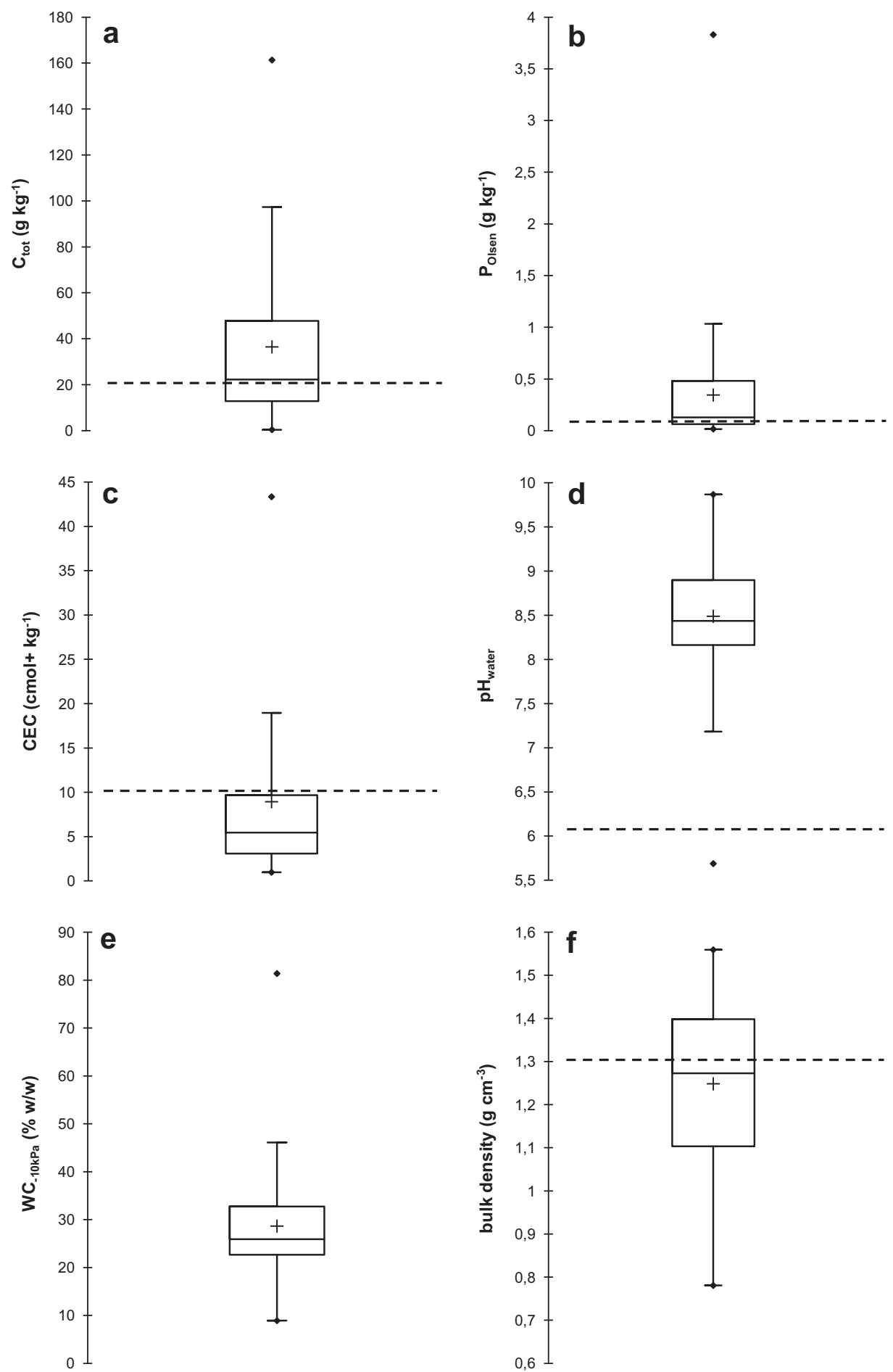

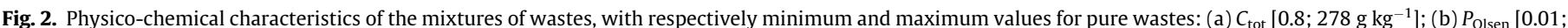

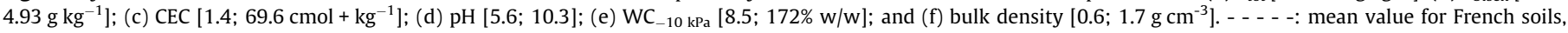
$n=2100$ (source: RMQS).

tios. The mixtures involving at minimum 15\% (w/w) CO, GW and SW would therefore be assimilated to humus-materials. Besides, another type of wastes (e.g., PM and SS) presents intermediate chemical properties comparable to organic amendments. They contribute to the hydraulic properties (hydraulic conductivity and water retention capacity) and the long-term potential of organic matter decomposition by bacterial and fungal activities. Nevertheless, with its high $\mathrm{pH}$ and $\mathrm{CaCO}_{3}$ content, PM presents a high risk of plant chlorosis, and should be used carefully. With bulk den- sities higher than $1.4 \mathrm{~g} \mathrm{~cm}^{-3}$ and adequate geo-mechanical properties a third type of wastes (e.g., CR, DR and TB) can mimic the stone matrix of structural soils (Grabosky et al., 2002; Bassuk et al., 2005). These wastes are similar to load bearing stones supporting pavement. Their influences on the chemical characteristics of the mixtures are low. However, an attention should be paid to potential leaching of undesirable compounds such as sulphate coming for example from gypsum (Nehls et al., 2013). Bricks constitute a specific type of waste. Considering mechanical properties, espe- 

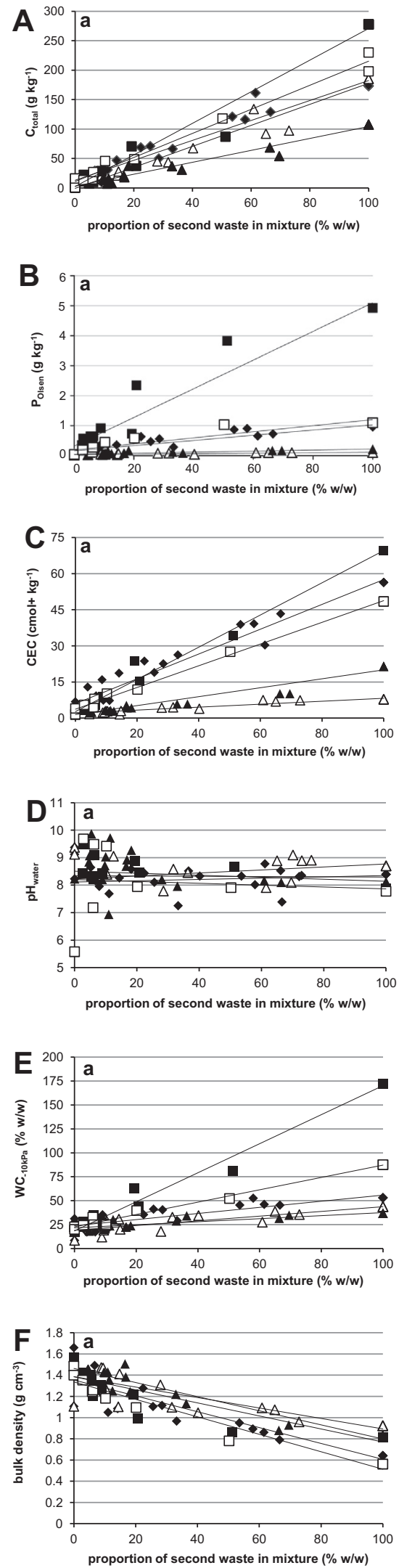
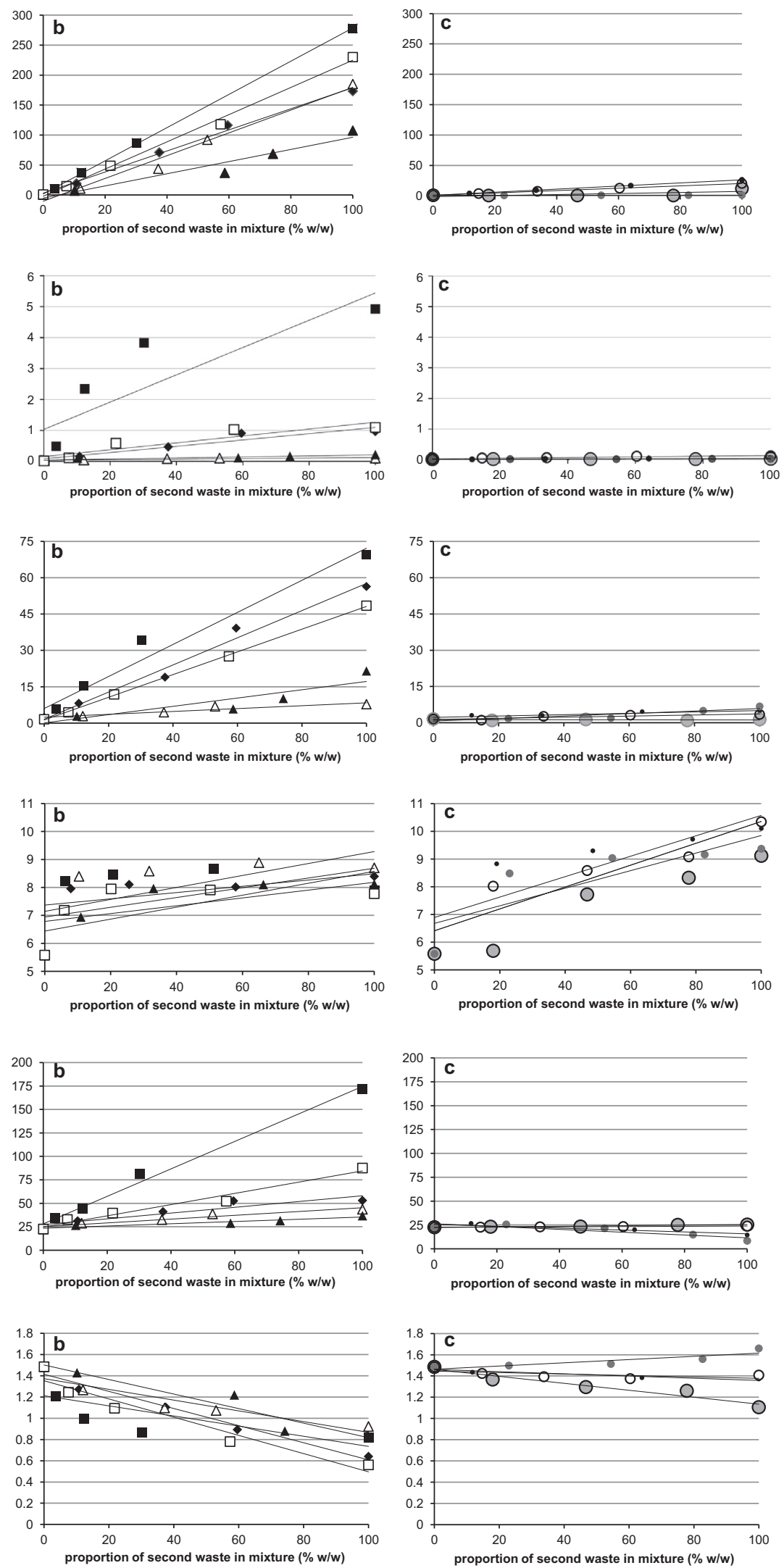

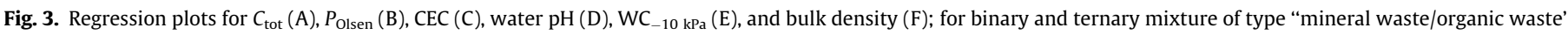

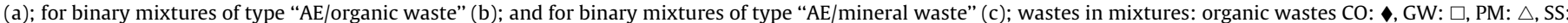

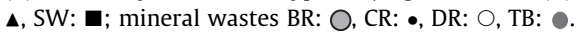



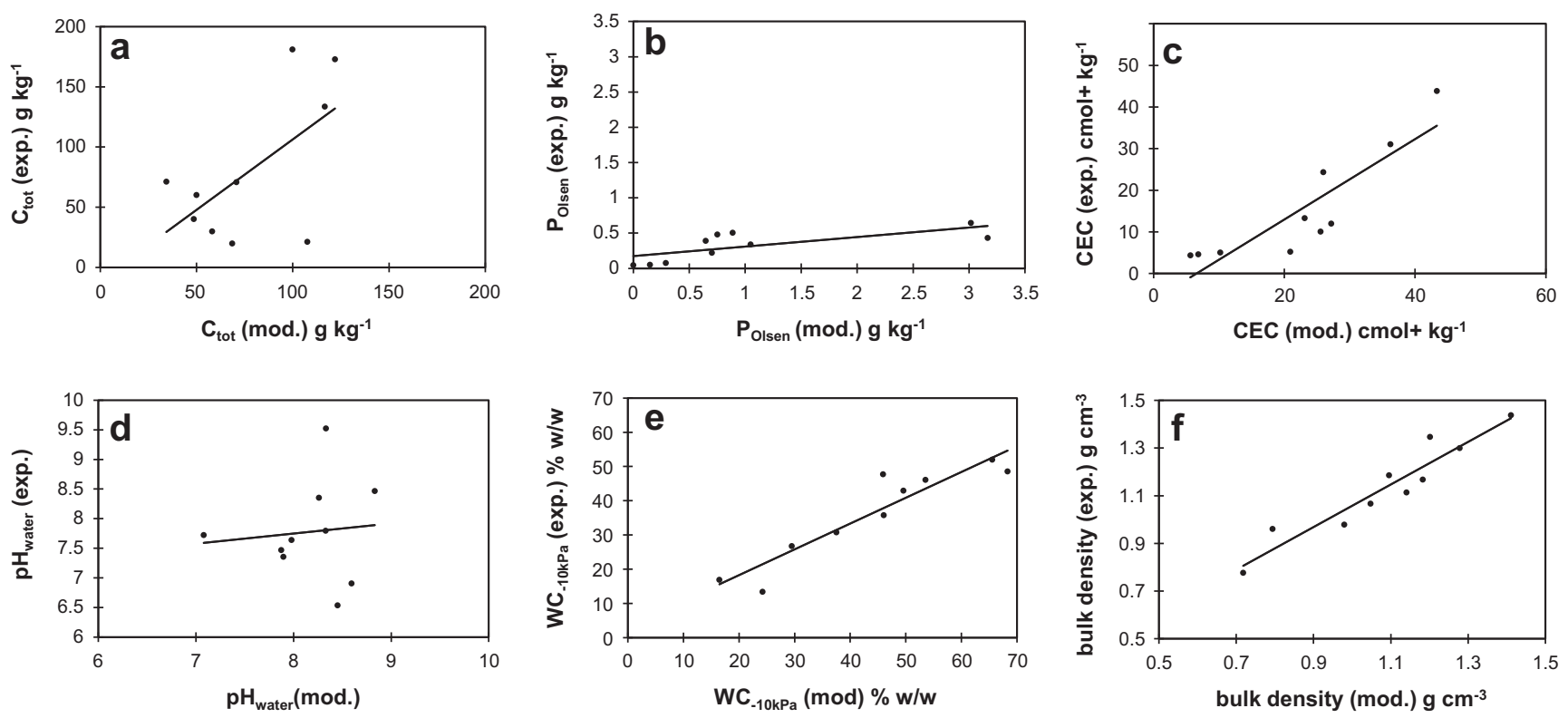

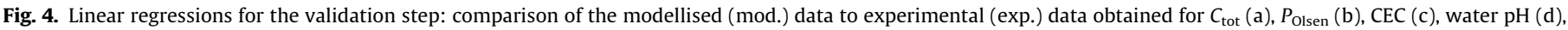

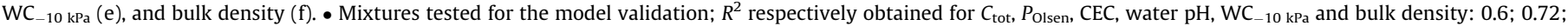
$0.88 ; 0.1 ; 0.93$ and 0.95 .

cially their friability, they cannot be considered as a structuring material. If they are not expected to influence the mixture properties (Nehls et al., 2013) to a large extent, except for $\mathrm{pH}$, they bring clay mineral to the media, enhancing exchange surfaces for nutrients. A last type of materials (e.g., AE and $\mathrm{BE}$ ) is characterised by low content of available nutrients but high water storage capacity.

\subsection{Mixtures of wastes can mimic a fertile soil}

Mixing wastes is necessary in order to obtain «artificial growth media» presenting satisfactory features for plant growth. The mixtures tested showed a large range of physico-chemical properties comparable to the median values obtained for French soils (statistics from the French monitoring network (RMQS)). The median values for $C_{\text {tot }}$ and $P_{\text {Olsen }}$ obtained on the wastes mixtures are quite higher (median of respectively 22.2 and $0.13 \mathrm{~g} \mathrm{~kg}^{-1}$ ) than the values obtained for French soils (19.6 and $0.03 \mathrm{~g} \mathrm{~kg}^{-1}$ ). The mixtures involving $\mathrm{CO}, \mathrm{GW}$ and $\mathrm{SW}$ that presented a high phosphorus supply can explain these differences. The median value for CEC in French soils $\left(10.2 \mathrm{cmol}+\mathrm{kg}^{-1}\right)$ was similar to that of the tested mixtures $\left(5.45 \mathrm{cmol}+\mathrm{kg}^{-1}\right)$. The $\mathrm{pH}$ values of the wastes mixtures are quite higher (median $=8.4$ ) than those in French soils (median $=6.2$ ). This phenomenon can be explained by the alkalinity of more than $80 \%$ of pure materials used in mixtures, materials that presented a high buffer capacity. Among a large majority of eligible wastes with high $\mathrm{pH}, \mathrm{AE}$ was the only candidate able to adjust the $\mathrm{pH}$ of some mixtures for optimal plant growth. Concerning the bulk density, the values obtained for the mixtures (median $=1.27 \mathrm{~g} \mathrm{~cm}^{-3}$ ) are very similar to the values for French soils (median = $1.31 \mathrm{~g} \mathrm{~cm}^{-3}$ ). Waste mixtures presented globally similar properties than mean French soils. Nevertheless the addition of some organic and organo-mineral wastes resulted in enhanced $P_{\text {Olsen }}$ concentrations and $\mathrm{pH}$ values. In this case, the constructed materials obtained by the proposed pedological engineering process presented features nearer to urban soils.

\subsection{A first step towards the design of a decision-making model}

This study constitutes a first step for the development of a decision-making aid model guiding for the formulation of wastes in pedological engineering. It can be considered as a preliminary tool for green spaces landscape designers to recycle wastes as substitutes to natural resources (e.g., upper soil materials, horticultural substrates and gravels). The results obtained in this study are based on two main assumptions: (i) soil agronomical analysis is transposable to wastes analysis; and (ii) the interpretation of these agronomic characterizations is the same for soils and for wastes mixtures. Only selected physical and chemical parameters have been taken into account, because they have been considered representative for global fertility. Further development of a decisionmaking aid model could take into account the mechanisms occurring during pedogenesis of young constructed soils involving various processes and their interactions depending on various factors (e.g., chemical reactivity, aggregation of constitutive wastes and mixtures, and biological activity). Indeed, the fresh mixtures were not submitted to natural climatic conditions, which would lead to a chemical and physical weathering of the components. Indeed, the pedogenesis of Technosols is already known to be fast and intense (Séré et al., 2010; Huot et al., 2012) and therefore unavoidable to take into account in this context.

\section{Conclusion}

The original purpose of this study was to focus on agronomic properties of waste mixtures resulting from soil construction processes. Dose-response curves describe the variation of physicochemical properties of mixtures depending on the type and ratio of selected wastes. If these mixtures mainly mimic natural soils, some of them present more extreme urban soil features, especially for $\mathrm{pH}$ and $P_{\mathrm{Olsen}}$. The fertility of the new substrates obtained after formulation of wastes is modelled by multilinear regressions for the main soil properties with decreasing fitness (water retention capacity = cation exchange capacity $>$ available phosphorus $=$ bulk density $>$ total carbon $>\mathrm{pH}$ ). The modelling approach confirms the initially proposed typology of wastes and enables to suggest thresholds for the proportion of each waste in mixtures. Nevertheless, the complex chemical interactions between wastes in binary and ternary mixtures have to be considered deeply for further development of the models, including a more mechanistic approach. Additional investigations should also be done on the effects 
of pedogenetical processes on the evolution of physico-chemical properties of constructed Technosols. These elements should be taken into account for developing a prediction tool of their fertility: this is the future cornerstone for soil eco-conception.

\section{Acknowledgements}

This work was supported by the ADEME (French Environmental Agency, SITERRE research project) and conducted within the framework of the GISFI (www.gisfi.fr). The authors wish to thank the technical staff of LSE (Adeline Bouchard, Stéphane Colin), of GISFI (Rémi Baldo, Lucas Charrois), master students (Manon Santeramo, Axel Roy) and all the partners involved in the SITERRE program for their substantial help. Some data used have been obtained within the framework of the GIS Sol (www.gissol.fr). The authors are grateful to Marion Bardy, head of InfoSol-INRA, and her colleagues for their substantial contribution.

\section{References}

ADEME, Déchets, Chiffres-clés, Edition 2012, ADEME éditions.

Arrouays, D., Jolivet, C., Boulonne, L., Bodineau, G., Grolleau, E., 2002. A new initiative in France: a multi-scale multi-institutional soil quality monitoring network. Comptes rendus de l'Academie d'Agriculture de France 88 (5), 93-103.

Bassuk, N., Grabovsky, J., Trowbridge, P., 2005. Using CU-Structural Soil in the Urban Environment. Urban Horticultural Inst, Cornell U.

Craul, P.J., 1999. Urban Soils: Applications and Practices. John Wiley \& Sons.

Fierro, A., Angers, D.A., Beauchamp, C.J., 1999. Restoration of ecosystem function in an abandoned sandpit: plant and soil responses to paper de-inking sludge. J. Appl. Ecol. 36 (2), 244-253.

Grabosky, J., Bassuk, N., Trowbridge, P., 2002. Structural soils: a new medium to allow urban trees to grow in pavement. Landscape architecture technical information series (LATIS). Am. Soc. Landscape Architects 636, 20001-23736.
Grosbellet, C., Vidal-Beaudet, L., Caubel, V., Charpentier, S., 2011. Improvement of soil structure formation by degradation of coarse organic matter. Geoderma 162 (1-2), 27-38.

Guyon, E., Troadec, J-P., 1994. Du sac de billes au tas de sable. Odile Jacob Editions. Huot, H. Simmonot, M.O., Marion, P., Yvon, J. De Donato, P., Morel, J.L., 2012. Characteristics and potential pedogenetic processes of a technosol developing on iron industry deposits. J. Soils Sediments, 1-14.

Jim, C., 1998. Urban soil characteristics and limitations for landscape planting in Hong Kong. Landscape Urban Plann. 10 (4), 235-249.

Jolivet, C., Boulonne, L., Ratié, C., 2006. Manuel du Réseau de Mesures de la Qualité des Sols. Unité InfoSol, INRA Orléans, France.

Khakhar, D.V., 2011. Rheology and mixing of granular materials. Macromol. Mater Eng. 296 (3-4), 278-289.

Lorenz, K., Lal, R., 2009. Biogeochemical C and N cycles in urban soils. Environ. Int. 35 (1), 1-8.

Marshall, R.E., Farahbakhsh, K., 2013. Systems approaches to integrated solid waste management in developing countries. Waste Manage. 33 (4), 988-1003.

Morel, J.L., Schwartz, C., Florentin, L., 2005. Urban soils. Encyclopedia Soils Environ., 202-208.

Nehls, T., Rokia, S., Mekiffer, B., Schwartz, C., Wessolek, G., 2013. Contribution of bricks to urban soil properties. J. Soils Sediments. 13 (3), 575-584.

Nielsen, T.S., Hansen, K.B., 2007. Do green areas affect health? results from Danish survey on the use of green areas and health indicators. Health Place 13 (4), 839850.

Paute, J.L., Marignier, J., Vidal, B., 1994. Le triaxial à changements répétés LPC pour l'étude des graves non traitées. Bulletin de liaison des Laboratoires des Ponts et Chaussées 190, 19-26.

Séré, G., Schwartz, C., Ouvrard, S., Sauvage, C., Renat, J.C., Morel, J.L., 2008. Soil construction: a step for ecological reclamation of derelict lands. J. Soils Sediments 8, 130-136.

Séré, G., Schwartz, C., Ouvrard, S., Renat, J.C., Watteau, F., Villemin, G., Morel, J.L. 2007. Early pedogenic evolution of constructed Technosols. J. Soils Sediments 10 (7), 1246-1254.

Severson, B.L., Snurr, R.Q., Ottino, J.M., 2007. Granular mixtures: analogy with chemical solution thermodynamics. J. Chem. Phys. 127, 174902.

Singh, R.P., Agrawal, M., 2008. Potential benefits and risks of land application of sewage sludge. Waste Manage. 28 (2), 347-358.

IUSS Working Group WRB. 2006. World Reference Base for soil resources 2006. second ed. World Soil Resources Reports No. 103. FAO, Rome.

Wright, A.L., Provin, T.L., Hons, F.M., Zuberer, D.A., White, R.H., 2008. Compost impacts on dissolved organic carbon and available nitrogen and phosphorus in turfgrass soil. Waste Manage. 28 (6), 1057-1063. 